\title{
An Empirical Investigation into the Impact of Change Management on Selected Manufacturing Firms in South East Nigeria
}

\author{
Nicholas N. Igwe ${ }^{1}$, Raph Chiemeka A. Nwokedi ${ }^{1} \&$ Sergius N. Udeh ${ }^{2}$ \\ ${ }^{1}$ Department of Business Management, Godfrey Okoye University Enugu, Thinkers' Corner Enugu, Nigeria \\ ${ }^{2}$ Department of Accounting/Finance, Godfrey Okoye University Enugu, Thinkers' Corner Enugu, Nigeria \\ Correspondence: Dr. Nicholas N. Igwe, Senior Lecturer, Department of Business Management, Godfrey Okoye \\ University Enugu, Thinkers' Corner Enugu, Nigeria. E-mail: ngozinick@yahoo.com
}

Received: August 30, 2013

Accepted: October 30, 2013

Online Published: January 12, 2014

doi:10.5430/ijba.v5n1p53

URL: http://dx.doi.org/10.5430/ijba.v5n1p53

\begin{abstract}
This paper seeks to investigate the effectiveness of change management and the level of commitment of top management of manufacturing firms in South Eastern Nigeria. Data were collected from two hundred and five (205) participant manufacturing firms who were financial members of Manufacturers Association of Nigeria (MAN). The Yamane's statistical formula was utilized for sample size determination. 267 copies of questionnaire were distributed to top and middle management staff who were knowledgeable about the technical information needed for implementing change management. Using Chi-square (X) statistic and Pearson product moment correlation coefficient, the study reveals that change management improves the level of performance and that there is a very strong positive relationship between commitment of top management, middle management and success rate of implementation in the selected firms. Based on these findings, the paper advocates that leaders and top management of these organizations should make the process of change management more conducive and organization friendly. Again employees who are going to be affected by change should earlier be identified with respect to their interest, knowledge and attitudes before implementation of change.
\end{abstract}

Keywords: empirical investigation, impact, change management, manufacturing firms

\section{Introduction}

\subsection{Background of the Study}

Many writers have characterized today's business environment as "hyper-competitive (D'Aveni, 1994; and Volberda, 1996), high velocity (Brown and Eisenhardt, 1997) or shaped by 'jolts' (Meyer, Brooks and Goes, 1990). In emerging economies such as the Nigeria one, these environmental features have been exacerbated by the globalization drive. In these circumstances, rapid adaptive organizational processes are essential to a firm's survival and success. From a social science perspectives, organizational adaptation is the ability of an organization to change itself or the way in which it behaves in order to survive in the face of external changes which were not predicted in any precise way when the organization was designed (Tomlinson, 1976). This definition confirms March's assertion that adaptation is essential to survival. Those organizations that do not adapt seem destined to expire (March, 1995).

In today's organization, change is inevitable and managers all over the world are adapting to changing market conditions and at the same facing the need for creating a proactive rather than a reactive managerial system. They are searching for ways to manage an increasingly complex technology and more sophisticated workforce or teams. To accomplish diverse goals, managers need more than piecemeal ad-hoc change programmes dealing only with current crises. They need change management techniques to prepare for future organizational competitive challenges, Drucker cited by Herbert (2002:2) succinctly put it in corporate parlance. "Managers must learn to build and manage a human group that is capable of anticipating the new, capable of converting its vision into technology, products, processes and services, willing and able to accept the new". Attempts to implement change management have been many and wide-ranging, but the promises made in its name have remained unfulfilled. There are three main causes for this:

- Mistakes continue to be made at the shop-floor level; 
- Bad examples have brought high-level management into discredit. In today's organizations many top executives start out heavily in the red as far as their credibility is concerned.

- The internal change story, circulated by organizations' communication channels to awaken the readiness and commitment of those affected, is frequently seen as pure rhetoric and rhapsodizing about change (Doppler, 2006).

Inspite of the aforementioned causes change remains a necessity. It is the only way for organizations to consistently adapt to new trends, react to competitors and meet the needs of their customers. The challenge facing Nigerian organizations therefore is not to avoid change and attain a state of changelessness. It is to manage change. That is seek change, initiate it, keep looking for something new to add, something old to discard and do all these with minimum undesirable effects as possible. Research on organizations have shown that organizations that do not change are compelled to change from existence to non-existence (Ejiofor, 1998 and March, 1995). Given the benefits of organizational change and the difficulty of successfully bringing it to fruition, there has been much debate over the last, two decades on the most appropriate way to bring about change (Pettigrew, 1990; Stacey, 2003; Dawson, 2003; Igwe, Chibuike and Alinno, 2012). There is a consensus amongst academics and practitioners that organizations are facing unprecedented levels of change and as a result the need to manage change and douce its effects successfully should be a core organizational competence.

\subsection{Statement of the Problem}

The contribution of the manufacturing sector to the Nigeria's Gross Domestic Product (GDP) is currently less than five percent. The current GDP figure of $\$ 194$ billion dollars places the country in the $41^{\text {st }}$ position, according to the International Monetary Fund (IMF) estimates of 2012 (The Guardian, 2012). At the heart of this problem of the real sector is the problem of competitiveness. The challenges for the industrial production and indeed real sector of the economy had persisted for over twenty years. Some of these challenges include: epileptic power supply; near absence of adequate distribution channels and a top-grade transportation network; rising cost of automotive gas oil and gas as well as uncoordinated tax administration system. Others are smuggling and trade malpractice; incessant increase in the monetary policy rate; difficulty in accessing long-term credits for small-scale manufacturing firms; achievement of a single digit interest rate and insecurity of lives and property due to nefarious activities of hoodlums, terrorists, militants and crude oil picketing mafias/pirates. The concomitant effects of all these challenges is that many manufacturing firms in Nigeria had decommissioned their plants and send their workers home to an uncertain future. Some of the manufacturing organizations had relocated to other West African nations with better macro-economic stability (Newswatch, 2009). Even the manufacturing firms seem not to help matters. There are issues with haphazard change management techniques in these organizations. The top echelons of the manufacturing firms are suspected of serving only their interest by manipulating relevant change management data. The implications of the above scenario pose a tremendous threat to both the manufacturing firms and the nation. To the firms they will not be able to improve productivity and create needed jobs. On the side of the government, the revenue accruable to the government by non-performing firms would be missed greatly. Thus the government's much trumpeted vision of the country joining the league of 20 most industrialized economies come 2020 is gradually turning into a slogan like many others before it such as Housing for All, Water for All etc.

\subsection{Objectives of the Study}

In order to develop an expanded theoretical foundation and understand how change management can be put into practice in Nigerian organizations, the objectives of the study are as follows:

- $\quad$ To find out the effectiveness of change management in improving organizational performance.

- To examine the level of commitment of top and middle management in the implementation of change management.

\subsection{Research Questions}

From the foregoing, the following research questions become imperative.

1. What is the effectiveness of change management in improving the level of performance in the selected organizations?

2. To what extent does top and middle management's commitment improves the success of change management project. 


\subsection{Statistical Hypotheses}

In view of the above research questions, the following hypotheses were formulated to guide the study:

i. Change management is effective in improving the level of organizational performance.

ii. There is a correlation between the commitment of top and middle management and success of change management project.

\section{Theoretical Considerations and Review of Related Literature}

Organizations can be viewed as dynamic systems of adaptation and change - two terms that are often used interchangeably that contain multiple parts which interact with one another and the environment (Morel and Ramanujan 1999). Existing views on adaptation and their definition of change differ with respect to;

(1) Whether the pressure for change reside within the organization or within its environment.

(2) Timing

(3) The radical nature of change. Change is often regarded as an organization's response to changes in external factors: threats and opportunities (Kraatz, 1998). As shown by Siggelkow and Levinthat (2005) authors such as Chandler (1962); Lawrence and Lorsch (1967) alluded to internal reasons for change and most life cycle models adhere to this perspective. A more inclusive view on change suggests that both external and internal pressures for change are relevant.

Defining change management is tough under any circumstances write Holland and Skarke (2003:24), especially in the context of new technology being implemented in an existing organization. Mention the issue of change management and a typical response to the question will be, "Does it really matter in the real word?" The answer to that question is "of course". After all definitions are important because they can provide clarity. In the simplest sense, change management means the process of helping a person, group or organization change. The world "management" implies an effort to plan the change and exert influence over other people in the process. Thus change management implies purposeful effort to bring about change. Kudray and Kleiner (1997:18) define change management as "the continuous process of aligning an organization with its market place - and doing it more responsively and effectively than competitors". For Anderson and Anderson (2001) Change management is seen as a set of principles, techniques and prescriptions applied to the human aspects of executing major change initiatives in organizational settings. Its focus is not on what is driving change (technology), reorganization plans, mergers and acquisitions (M \& A) Udeh \& Igwe, 2013, globalization etc. but on 'how' to orchestrate the human infrastructure that surrounds key projects so that people are better prepared to absorb the implications affecting them. Change management is one of the Human resource management (HRM) processes that contributes to or underpins the activities of human resources department or unit in an organization. It is concerned with advising and assisting with the facilitation of change in organizations in response to changes in the environment and the introduction of new organizational structures and systems, human resource policies and practices (Armstrong, 2005). Organizational change has also been referred to as organizational development and organizational transformation (Cummings, and Worley, 2005). For this paper change management is seen as the process that is used to help all the stakeholders adapt successfully to the changes that are taking place in the organization. It is meant to shift stakeholders from their current state to a desired future state.

According to the Greek Philosopher Heraclitus, "There is nothing permanent but change". By that he meant that everything is always in a flux. As the Chinese adage suggests no one can step in the same river twice, because the river is always in motion and is therefore always changing. The world has seen radical change in global markets and national economics. The exit world is getting more interconnected and the economies and industries have become global. There are crises in financial institutions, the housing market, education, health care and emerging markets to mention only a few major issues. On the positive side nanotechnology, green technology, unified communications technology, visualization technologies, social software and information systems - the whole technology world will bring advances beyond our imagination. These technologies will inevitably impact the way we manage in different organizations.

Rothwell, Prescott and Taylor $(1998,2008)$ had identified six key changes that would have the greatest impact in the workplace and workforce over the next ten years. The list is as highlighted below:

- $\quad$ Changing technology;

- Increasing globalization;

- $\quad$ Continuing cost containment 
- Increasing speed in market change

- $\quad$ The growing importance of knowledge capital; and

- Increasing rate and magnitude of change

Changing technology refers to rapid advancement in human knowledge. Increasing globalization refers to the impact that rapid transportation and global communications have on how organizations conduct business. Continuing cost containment refers to efforts undertaken by organizations to address declining profit margins, brought by the ease of price comparison through web-based technology. To maintain a profitable business, organizations are making efforts to improve profits by reducing the costs of business operations. Increasing speed in market change refer to the continuing importance of beating competitors to the punch by meeting the rapidly changing tastes of consumers. The growing importance of knowledge capital refers to the key value-added capabilities of human creativity and innovation to identify new businesses, products, services and markets. Finally, the increasing rate and magnitude of change refers to the increasing speed and scope of changes that are occurring. In short change itself is changing and posing ever-more-daunting challenges for business leaders who need to respond in real time to breaking events.

A search through the literatures (Brown and Eisenhardt (1997); Ejofor (1998); Herbert (2002); Robbins (2005); Kieffer, (2005) Pryor, Taneja, Humphreys, Anderson and Singleton, (2008) revealed that each trend influences the others. The definition of each trend may vary by organizational context and even functional area. The trends are related in that many are the root causes of other trends. And each trend required new competencies from leaders to respond to or even anticipate the changes brought by each trend. Nowadays these changes can be seen almost in all types of organizations (the manufacturing firms inclusive) in Nigeria. They constitute organizational downsizing, continuous improvement, globalization of industries, Mergers and Acquisitions (Palmer, Dunford and Akin, 2009); Udeh and Igwe, (2013).

Regardless of change speed, organizational change is the movement of an organization from the existing plateau toward a desired future state in order to increase organizational efficiency and effectiveness (Cummings and Worley, 2005; George and Jones, 2002; Pryor and et al, 2008). Conclusions drawn by these researchers are that the driving motives for change management are the result of the need to constantly improve productivity and efficiency (Arnetz, 2005, Pryor et al, 2008, Igwe, Chibuike and Alinno, 2012). This creates the need for further studies into the effect of such change management on manufacturing firms such as this research, which will inform policies linked to the federal government's desires of the country joining the league of twenty (20) most industrialized economics come 2020 .

In essence what the successful Nigerian manufacturing organizational leaders and managers should strive to do is to transform their respective organizations by developing and deploying new visions, missions, values, goals, strategies and structures that show a continuously changing organizations with capacity and capability to undergo transformation. This would help them key into the transformational agenda of the current Nigeria Federal Administration. This definitely makes such organizations to proactively drive innovations to the extent that they become major players for change within the macro-economic environment.

\section{Methodology}

For this study, the survey research method was adopted (Eboh, 2009). The objective of the study was to investigate the impact of change management implementation as applied to the manufacturing sector in South East Nigeria. 205 participant manufacturing organizations were identified through published literature such as trade journals and data base of Manufacturers Association of Nigeria (MAN). The study lasted for two years $(2009-2011)$. The instruments for data collections were questionnaire and structured interviews. The questionnaire was administered to top management and middle management staff of 267 respondents using Yamane (1964) for sample size determination (Appendix I). The questionnaire and structured interview questions were designed by the researchers. Some colleagues from the Faculty of Business Administration, University of Nigeria Nsukka who were experienced and knowledgeable in the construction of research instruments validated the instruments. Consequently, some items were added while a few others were re-written. The computed sample size was allocated proportionally to the selected states depending on the proportion of the manufacturing firms that came from each state using Kumar (1976) proportional allocation formula (Appendix ii). The questions were optioned using five (5) Likert type of responses namely: Strongly Agree, Agree, Neutral, Disagree and Strongly Disagree.

As indicated earlier, the study included interviews with senior managers who agreed to be interviewed. They were asked to indicate their availability and eagerness in the questionnaire. These managers were influential in developing change management interventions and so powerful in influencing implementation strategies. As it was expected that 
Human Resource (HR) practitioners, would be most likely to provide reliable information on change managements. Managers in the Human Resources departments were identified and chosen for this exercise.

A total of 267 copies of the questionnaire were administered out of which seven (7) were cancelled while ten (10) were not returned. As a result, 250 (93.6 percent) were used for analysis. A combination of Chi-Square statistic and Pearson Product Moment correlation coefficient were used to test the stated hypotheses at 0.05 level of significance. These techniques were adopted because the samples of the variables were randomly selected from the population.

Table 1. Distribution of questionnaire among the South East states of Nigeria (Man members)

\begin{tabular}{clccc}
\hline S/N & State & $\begin{array}{c}\text { Number of Selected } \\
\text { Organizations }\end{array}$ & $\begin{array}{c}\text { No. of Top Management } \\
\text { and Middle Management } \\
\text { Staff }\end{array}$ & $\begin{array}{c}\text { No. of } \\
\text { Questionnaire } \\
\text { served }\end{array}$ \\
\hline 1. & Abia & 35 & 105 & 35 \\
2. & Anambra & 135 & 540 & 179 \\
3. & Ebonyi & Nil & Nil & - \\
4. & Enugu & 22 & 88 & 29 \\
5. & Imo & 13 & 72 & 24 \\
\hline & Total & $\mathbf{2 0 5}$ & $\mathbf{8 0 5}$ & $\mathbf{2 6 7}$ \\
\hline
\end{tabular}

Source: Field Survey, 2011 and Statistical Analysis

\section{Result and Discussion}

In this paper, the impact of change management implementation on selected manufacturing firms in Southeast Nigeria was investigated. In this section, the findings in relation to the objectives of the study are presented and discussed:

i. The extent change management is effective in improving organizational performance. The finding of this objective reveals that change management was effective in improving the level of performance in the selected organizations in South East Nigeria. This result agrees with Anderson and Anderson, (2001); Dawson, (2003) and Armstrong, (2005). These authors see change management as a set of principles, techniques and prescriptions applied to the human aspects of implementing change initiatives in organizational settings. Again Kudray and Kleiner, (1997) had remarked that change management is the continuous process of aligning an organization with the realities of its market place and doing more responsively and effectively than competitors. It is heart-warming to note that many of the sampled firms agreed that people who would be affected by change management implementation must be involved in the work of structuring it from the outset. This shows that some of the manufacturing firms are aware of global practices in change management implementation. Table 2 gives more insight.

\section{Computation of Hypothesis One (1)}

Change management is effective in improving organizational performance of the selected manufacturing organizations.

The test statistic used is the chi-square, $\mathrm{X}^{2}$.

\section{Relevant Questions:}

- $\quad$ Change management can improve employees' performance and productivity

- Change management can lead to a better utilization of employees in this organization.

Table 2. Contingency table on the effectiveness of change management in improving organizational performance

\begin{tabular}{lcccccc}
\hline OPTIONS & \multicolumn{5}{c}{ RESPONSES } \\
\cline { 2 - 6 } & SA & A & N & DA & SD & Row Total \\
\hline $\begin{array}{l}\text { Change management can improve employees } \\
\text { performance and productivity }\end{array}$ & & & & & & \\
& 120 & 80 & 10 & 30 & 10 & 250 \\
\hline $\begin{array}{l}\text { Change management can lead to a better } \\
\text { utilization of employees in the organization }\end{array}$ & 110 & 90 & 20 & 30 & 0 & 250 \\
\hline Column Total & $\mathbf{2 3 0}$ & $\mathbf{1 7 0}$ & $\mathbf{3 0}$ & $\mathbf{6 0}$ & $\mathbf{1 0}$ & $\mathbf{5 0 0}$ \\
\hline
\end{tabular}

Source: Field Survey, 2011. 
Where

SA - Strongly Agree

A - Agree

$\mathrm{N}$ - Neutral

DA - Disagree

SD - Strongly Disagree

Table 3. The computed observed and expected frequencies of sample results

\begin{tabular}{|c|c|c|c|c|c|c|c|c|}
\hline \multirow{2}{*}{\multicolumn{3}{|c|}{ OPTIONS }} & \multicolumn{6}{|c|}{ RESPONSES } \\
\hline & & & SA & $\frac{\mathbf{A}}{80(85)}$ & $\mathbf{N}$ & \multirow{2}{*}{$\frac{\text { DA }}{30(30)}$} & SD & Row Total \\
\hline $\begin{array}{l}\text { Change mana } \\
\text { employees' } \\
\text { productivity. }\end{array}$ & $\begin{array}{r}\text { ement } \\
\text { perfo }\end{array}$ & $\begin{array}{cr}\text { can } & \text { improve } \\
\text { rmance } & \text { and } \\
& \end{array}$ & $120(115)$ & $80(85)$ & $10(15)$ & & $10(05)$ & \\
\hline $\begin{array}{l}\text { Change manages } \\
\text { utilization of em }\end{array}$ & $\begin{array}{l}\text { nent ca } \\
\text { loyees }\end{array}$ & an lead to a better & $110(115)$ & $90(85)$ & $20(15)$ & $30(30)$ & $0(05)$ & 250 \\
\hline Column Total & & & 230 & 170 & 30 & 60 & 10 & 500 \\
\hline Statistic & $=$ & $\mathrm{X}^{2}$ & & & & & & \\
\hline ef of Freedom & $=$ & 4 & & & & & & \\
\hline of Significance & $=$ & 0.05 & & & & & & \\
\hline al value & $=$ & 9.49 & & & & & & \\
\hline lated value & $=$ & 14.35 & & & & & & \\
\hline
\end{tabular}

Decision: Since the computed value (14.35) is greater than the critical value (9.49), we conclude that change management is effective in improving the level of organizational performance of the selected manufacturing organizations.

ii. The extent top management and middle management are committed in the successful implementation of change management. The findings of this objective reveal a very strong positive relationship between commitment of top management and success rate of change management projects amongst the sampled manufacturing firms in Nigeria. Table 4 and appendix iv attest to this assertion. This finding agrees with the writings of Currie (1999); Huy (2002); Floyd and Lane (2000) who in their different perspectives view middle management as strategic assets championing new ideas, facilitating adaptability and synthesizing strategic information for senior managers in formulating strategies. Engagement of top management goals and support are a sine qua non for a successful change management readiness (Igwe, Chibuike and Alinno, 2012). Lack of genuine management support is one of the most frequent causes of implementation failure. However, this investigation reveals that the sampled manufacturing firms seem to place more emphasis on organizational downsizing, continuing cost containment and value added capabilities of human creativity and innovation to survive the inherent harsh manufacturing environment in Nigeria. (Table 4 throws more light).

Table 4. Contingency table for the correlation between the commitment of top management and success of change management project

\begin{tabular}{|c|c|c|c|c|c|}
\hline $\begin{array}{c}\mathrm{N} \text { (paid values) of } \\
X \\
\text { and } Y\end{array}$ & $\begin{array}{c}\text { In this } \\
\text { organization } \\
\text { the level of } \\
\text { commitment } \\
\text { of top } \\
\text { management } \\
\text { is high }=X\end{array}$ & $\begin{array}{l}\text { Provision of } \\
\text { Fund for a } \\
\text { successful } \\
\text { change } \\
\text { management } \\
\text { project was } \\
\text { provided by } \\
\text { top } \\
\text { management }\end{array}$ & $\mathbf{X} 2$ & Y2 & XY \\
\hline Strongly Agree & 100 & 120 & 10,000 & 14,400 & 12,000 \\
\hline Agree & 60 & 80 & 3,600 & 6,400 & 4,800 \\
\hline
\end{tabular}




\begin{tabular}{lccccc}
\hline Neutral & 30 & 20 & 900 & 400 & 600 \\
\hline Disagree & 30 & 20 & 900 & 400 & 600 \\
\hline Strongly Disagree & 30 & 10 & 900 & 100 & 300 \\
\hline $\mathbf{N}=\mathbf{5}$ & $\Sigma \mathbf{X}=\mathbf{2 5 0}$ & $\Sigma \mathbf{Y}=\mathbf{2 5 0}$ & $\Sigma \mathbf{X}^{2}=\mathbf{1 6 , 3 0 0}$ & $\sum \mathbf{Y}^{2}=\mathbf{2 1 , 7 0 0}$ & $\begin{array}{c}\sum \mathbf{X Y}= \\
\mathbf{1 8 , 3 0 0}\end{array}$ \\
\hline
\end{tabular}

Source: Field Survey, 2011.

Test statistic $=$ Pearson's product moment correlation coefficient

Degree of Freedom $\quad=\quad \mathrm{N}-2=3$

Number of Pairs $=5$

Level of significance $\quad=\quad 0.5$

Critical value $\quad=2.35$

$\mathrm{r}$ (rho) $\quad=0.9809$

Source: Statistical Analysis (Appendix IV).

Decision Rule: Reject $\mathrm{H}_{0}$, if $\mathrm{t}$ computed is $>\mathrm{t}$ critical, otherwise do not reject (accept).

Decision: The $t$ computed (8.49) $>t$ critical (2.35). Then we accept the alternative hypothesis which states that when the level of top management commitment is high in the implementation of a change management project, the success rate of such project tends to be higher.

\section{Conclusion and Recommendations}

This study had investigated the effectiveness of change management in improving organizational performance and the relationship between the level of commitment of top and middle management in success of implementation from 2009 to 2011. The study revealed that change management was effective in improving the level of organizational performance and that the commitment and genuine support of top and middle management were a sine qua non for success in managing its implementation.

In relation to the objectives, the researchers made the following recommendations:

i. Leaders and top management of manufacturing organizations have to understand the requirements of managing change among employees by making the process more conducive and environment friendly. This will improve the positive attitude, the internal core and dynamic capabilities of employees in adapting to changes in their internal and external environment.

ii. Employees who will be affected by change management implementation must be involved in the work of structuring it from the outset. The minimum form of involvement is constant communication and not information.

iii. In order to get employees affected involved, they need to be identified at the beginning with respect to their interest, knowledge, attitude towards implementation and their mental state. This is because employees who are passing through major life transitions such as bereavement, relocation hassles, redundancy threats are never committed to implementing change management project.

iv. Verbal reinforcement of new behaviour that fit into the organizational change should be encouraged by organizational leaders and managers. This will increase employee repetition of those new change behaviours expected of them. This will help to extinguish old behaviour and allow the new take root in the individual employee.

v. Nigeria government at all levels should continue to create and provide the needed environment for these manufacturing firms to survive and thrive bearing in mind that the operating environment is still far from conducive and friendly.

\section{Acknowledgements}

The authors would like to thank Prof. F. C. Eze, the registrar of Godfrey Okoye University, Enugu and the dean of the faculty of Management and Social Sciences, Prof. Eugene Nwadialor for their invaluable supports and insights. 


\section{References}

Anderson, L. A., \& Anderson, D. (2001). The Change Leaders' Roadmap: How to Navigate your Organization's Transformation. San Francisco: Pfeffer.

Armstrong, M. (2005). A handbook of Human Resource Management Practice. London: Kogan Page Publishers.

Arnetz, B. B. (2005). Subjective indicators as a Gauge for Improving Organizational well-being, An attempt to apply the Cognitive Activation Theory to Organizations. Pschoneuroendocrinology, 30, 1022-1026. http://dx.doi.org/10.1016/j.psyneuen.2005.03.016

Brown, S. L., \& Eisenhardt, K. M. (1997). The Art of Continuous Change: Linking Complexity Theory and Time Paced Evolution in Relentlessly Shifting Organizations. Administrative Science Quarterly, 42, 125-140. http://dx.doi.org/10.2307/2393807

Chandler, A. D. (1962). Strategy and Structure. Mass: MIT Press.

Cummings, T. G., \& Worley, C. G. (2005). Organizational Development and Change ( $8^{\text {th }}$ ed). Mason. OH: South Western College Publishing.

D’Aveni, R. A. (1994). Hyper Competitions. New York: The Free Press Publishers.

Dawson, P. (2003). Reshaping Change in Processional Perspectives. London: Routledge. http://dx.doi.org/10.4324/9780203451830

Doppler, K. (2006). Change Management in Business. The Ultimate Resource. Cambridge: A and K Black Publishers.

Eboh, E. C. (2009). Social and Economic Research: Principles and Methods. Enugu: African Institute for Applied Economics.

Ejiofor P.N.O. (1998). Management of Change. In L. O. Onyemelukwe (Ed.), Management of Change. Awka: Future Tech. Publishers.

George, J. M., \& Jones, G. R. (2002). Understanding and Managing Organizational Behaviour. Upper Saddle River New Jersey: Prentice Hall.

Herbert, W.E. (2002) Change Management and Management of Organization, Paper presented at the mandatory continuing Professional development of Association of National Accounts of Nigeria (ANAN), March 26-28, Jos.

Holland, D., \& Skarke, G. (2003). Change Management for Big Systems. Journal of Industrial Management, 45, 24-36.

Igwe, N. N., Chibuike V.C., \& Alinno F. C. (2012). The Readiness of Organizations for a Successful Change Management in a Hyper-Competitive Environment. International Bilingual and Multi-Disciplinary Journal of Contemporary Issues and Development Studies, 1(2), 21-38.

Kieffer, T. (2005). Feeling Bad: Antecedents and Consequences of Negative Emotions in ongoing Change. Journal of Organizational Behaviour, 26, 875-897. http://dx.doi.org/10.1002/job.339

Kraatz, M. S. (1998). Learning by Association, Interorganizational Networks and Adaptation to Environmental Change. Academy of Management Journal, 41, 6. http://dx.doi.org/10.2307/256961

Kudray, L., \& Kleiner, B.H. (1997). Global Trends in Managing Change. Journal of Industrial Management, 39, $18-20$.

Kumar, R. S. (1976). A Manual of Sampling Techniques. London: Heinemann Limited.

Lawrence, P. R., \& Lorsch, J. W. (1967). Organization and Environment: Managing Differentiation and integration. Boston: Harvard Business School Press.

March, J. G. (1995). The Future Disposal Organizations and the Rigidities of Imagination. Organization Science, $2,1$. http://dx.doi.org/10.1287/orsc.2.1.1

Mayer, J. W., Brooks, G., \& Goes, J. B. (1990). Environmental Jolts and Industry Revolutions: Organizational Response to Discontinuous Change. Strategic Management Journal, 11, 261-273. 
Morel, B., \& Ramanujan, R. (1999). Through the Looking Glass of Complexity: The Dynamics of Organizations as Adaptive and Evolving Systems. Journal of Organization Science, 10, 2. http://dx.doi.org/10.1287/orsc.10.3.278

Newswatch. (2009). The Fall of the Giant 50, 14, 20.

Palmer, I., Dunford, R., \& Akin, G. (2009). Managing Organizational Change: A Multiple Perspectives Approach ( $2^{\text {nd }}$ ed.). New York: McGraw Hill.

Pettigrew, A. M. (1990). Studying Strategic Choice and Strategic Change. Organizational Studies, 11, 6-11. http://dx.doi.org/10.1177/017084069001100102

Pryor, M. G., Taneja, S. Humphreys J, Anderson, D., \& Singleton, L. (2008). Challenges Facing Change Management: Theories and Research. Delhi Business Review, 9(1), 1-15.

Robbins, S. P. (2005). Organizational Behaviour (1 ${ }^{\text {th }}$ ed.). Upper Saddle River, New Jersey: Pearson Education Inc.

Rothwell, W., Prescott, R., \& Taylor, M. (1998). Strategic Human Resource Leader: How to Prepare your Organizations for The Six Key Strategic Trends Shaping the Future. Palo Alto: Davies - Black.

Rothwell, W., Prescott, R., \& Taylor, M. (2008). Human Resources Transformation: Demonstrating Strategic Leadership in the Face of Future Trends. Palo Alto: Davies-Black.

Siggelkow, N., \& Levinthal, D. A. (2005). Escaping Real (Non-benign) Competency Traps: Linking the Dynamics of Organizational Structure to the Dynamics of Search. Strategic Organization, 3, 1. http://dx.doi.org/10.1177/1476127005050521

Stacey, R. D. (2003). Strategic Management and Organizational Dynamics. The Challenge of Complexity, Harlow: Prentice Hall.

The Guardian Newspaper. (2012). Vision 20:2020: A vision on the death. March, 21, pp. 8-9.

Tomlinson, R. C. (1976). Organizational Design and Adaptivity, Omega, 4, 1. http://dx.doi.org/10.1016/0305-0483(76)90004-9

Udeh, S. N., \& Igwe, N. N. (2013). Effects of Mergers and Acquisitions on Return on Capital Employed and Dividend per Share Indices of Companies in Nigeria. International Journal of Business Administration, 4(5), 51-72. http://dx.doi.org/10.5430/ijba.v4n5p51

Volberda, H. W. (1996). Toward the Flexible Form: How to Remain Vital in Competitive Environments. Organization Science, 7, 1. http://dx.doi.org/10.1287/orsc.7.4.359

Yamane, T. (1964). Statistics: An Introductory Analysis. London: Harper and Row.

Appendix I. Sample size determination using Yamane (1964) formula

$$
\begin{aligned}
& \mathrm{n}=\frac{\mathrm{N}}{1+\mathrm{N}\left(e^{2}\right)} \\
& \text { Where } \\
& \mathrm{n}=\text { Sample size } \\
& \mathrm{N}=\text { Finite population } \\
& \mathrm{e}=\text { Level of significance } \\
& \mathrm{I}=\text { Unity (a constant) } \\
& \mathrm{n}=\frac{805}{1+805(0.05)^{2}} \\
& =\frac{805}{1+2.0125} \\
& =\frac{805}{3.0125} \\
& =\mathbf{2 6 7 . 2 2}
\end{aligned}
$$


Appendix II. Questionnaire distribution format

Applying Kumar (1976) proportional allocation formula for the manufacturing firms in South East States of Nigeria.

$\mathrm{nh}=\frac{\mathrm{n}(\mathrm{Nh})}{\mathrm{N}}$

Where

$\mathrm{Nh}=$ Group population from each stratum

$\mathrm{n}=$ Overall sample size

$\mathrm{N}=$ The overall population

$\mathrm{nh}=$ Sample size from each stratum, in this case each state.

For Abia State:

$$
\begin{aligned}
\mathrm{nh}=\frac{\mathrm{n}(\mathrm{Nh})}{\mathrm{N}}=\frac{267 \times 105}{805} & =34.8 \\
& =\mathbf{3 5}
\end{aligned}
$$

\section{For Anambra State}

$\mathrm{nh}=\frac{\mathrm{n}(\mathrm{N} \mathrm{h})}{\mathrm{N}}=\frac{267 \times 540}{805}=179$

For Ebonyi State: None of the manufacturing organization in the state is a bona fide (financial) member of Manufacturing Association of Nigeria (MAN) at the time of this investigation.

For Enugu State:

$\mathrm{nh}=\frac{\mathrm{n}(\mathrm{N} \mathrm{h})}{\mathrm{N}}=\frac{267 \times 88}{805}=39.2$

For Imo State:

$$
\begin{gathered}
\mathrm{nh}=\frac{\mathrm{n}(\mathrm{Nh})}{\mathrm{N}}=\frac{267 \times 72}{805}=23.88 \\
=\mathbf{2 4}
\end{gathered}
$$

Appendix III. Computation of Hypothesis one from sample result

Test statistic: The Chi-Square $\left(\mathrm{X}^{2}\right)$ is applied at 5 percent level of significance.

Let $\mathrm{X}=0.05$

Degree of Freedom, D.F. $\quad=\quad(\mathrm{r}-1)(\mathrm{c}-1)$

$$
\begin{aligned}
& =(5-1)(2-1) \\
& =\quad(4)(1)
\end{aligned}
$$$$
=4
$$

Critical value $=9.49$

To compute the expected we apply,

$$
\begin{array}{rlrl}
\text { eji } & =\frac{\text { (row total })(\text { column to tal })}{\text { Overall total }} & \\
& =\frac{250 \times 230}{500} & & \\
& =\frac{250 \times 15}{500} & &
\end{array}
$$




$$
\begin{aligned}
& =\frac{250 \times 30}{500}=15 \\
& =\frac{250 \times 60}{500}=30 \\
& =\frac{250 \times 10}{500}=05 \\
& \mathrm{X}_{i}^{2}=\frac{\mathrm{oj}-\mathrm{ej}}{\mathrm{ej}} \\
& =\frac{(120-115)^{2}}{115}+\frac{(10-115)^{2}}{115} \\
& =0.22+0.22 \\
& =0.44 \\
& \mathrm{X}_{i i}^{2}=\frac{\mathrm{oj}-\mathrm{ej}}{\mathrm{ej}} \\
& =\frac{(80-85)^{2}}{85}+\frac{(90-85)^{2}}{85} \\
& =0.29+0.29 \\
& =0.58 \\
& \mathrm{X}_{\text {iii }}^{2}=\frac{(10-15)^{2}}{15}+\frac{(20-15)^{2}}{15} \\
& =\frac{25}{15}+\frac{25}{15} \\
& =1.67+1.67 \\
& =3.33 \\
& X_{i v}^{2}=\frac{(30-30)^{2}}{30}+\frac{(30-30)^{2}}{30} \\
& =0 \\
& X_{v}^{2}=\frac{(10-05)^{2}}{05}+\frac{(0-05)^{2}}{05} \\
& =\frac{25}{5}+\frac{25}{5} \\
& =05+05 \\
& =10
\end{aligned}
$$

Total $=0.44+0.58+3.33+0+10.00=14.35$ 
Appendix IV. Computation of hypothesis two

$\gamma=\frac{\mathrm{N} \sum \mathrm{XY}-\left(\sum \mathrm{X}\right)\left(\sum \mathrm{Y}\right)}{\sqrt{\left[\mathrm{N} \sum \mathrm{X}^{2}-\left(\sum \mathrm{X}^{2}\right)\right]\left[N \sum \mathrm{Y}^{2}\left(\sum \mathrm{Y}\right)^{2}\right]}}$

By substitution

$=\frac{5(18,300)-(250)(250)}{\sqrt{\left[5(16,300)-250^{2}\right]\left[5(21,700)-(250)^{2}\right]}}$

$=\frac{91,500-62,500}{\sqrt{[81,500-62,500][108,500-62,500]}}$

$=\frac{29,000}{\sqrt{[19,000][46,000]}}$

$\gamma=\frac{29,000}{874,000,000}$

$\gamma=\frac{29,000}{29563.49}$

$\gamma=0.9809$

The computation of $\gamma$ gave a value of 0.9809 indicating a very strong positive relationship between commitment of top management and success of change management project.

Transformation of the result of Pearson's Product Moment Correlation to t-test is as follows

$\mathrm{t} \quad=\quad \gamma \sqrt{\frac{\mathrm{N}-2}{\mathrm{n}-\mathrm{r}^{2}}}$

Where

$\mathrm{N}-2=$ degree of freedom

$\mathrm{n}=$ number of paid values

$\mathrm{t}=\mathrm{t}$-statistic

$\gamma \quad=0.9809=$ correlational coefficient

$\mathrm{t}=\sqrt[0.98]{\frac{5-2}{1-0.98^{2}}}$

$=\sqrt[0.98]{\frac{3}{1-0.9604}}$

$=\sqrt[0.98]{\frac{3}{0.04}}$

$=\sqrt[0.98]{75}$

$\mathrm{t}=0.98 \times 8.660$

$=8.49$

Appendix V. List of financial member companies in Anambra/Enugu/Ebonyi States Branch arranged according to sectoral grouping

\section{A. FOOD, BEVERAGES \& TOBACCO GROUP}

NO. NAMES

1. Bons West Africa Ltd

Published by Sciedu Press

\section{ADDRESS}

Km2 Enugu/Onitsha Exp. Road, Trans-Ekulu Box 21, 
2. Bounatine Ventine (Nig) Ltd.

3. Delta Flour Mills Nig. Ltd.

4. Eastern Distilleries Food Ind. Ltd.

5. Envoy Oil Industries Ltd.

6. Golden Oils Inds. Ltd.

7. Ibeabuchi Nig. Ltd.

8. Life Breweries Co. Ltd.

9. Mikson Industries Ltd.

10. Niccus Industries Ltd.

11. Nigerian Breweries Plc.

12. Nigerian Mineral Water Ind. Ltd.

13. Nigerian Starch Mills Ltd.

14. Ogenna Rice Mills Ltd.

15. Pokobros Foods \& Chemical Ind. Ltd

16. Poko Oils Mills Ltd.

17. Resources Improvement \& Mfg. Co. Ltd.

18. Shrifats \& Magarine Ltd.

19. Union Oak Farms \& Inds. Ltd.

20. Zubee International Co. Ltd

21. VAC Industries (Nig.) Ltd.

B. CHEMICAL AND PHARMACEUTICAL SECTORAL GROUP

NO. NAMES

AESF AP Ltd.

A-Z Petrochemicals Ind. Ltd.

Beta Cosmetic Ind. Co. Ltd.

C.C. Umeji Agro Allied Co. Ltd

Ceenek Pharm. Ind. Ltd.

Dezem Nig. Ltd.

Dover Inds. Ltd.

Duemen Chemical Ltd.

Emy Holdings Nig. Ltd

E. Amobi Mfg. Co. Ltd.

Euco Inds. Ltd.

Emos Best Ind. Ltd.

Franoson Mannyon Int. Ltd.

Gafa Industries Nig. Ltd.

Group Enterprises (Nig) Ltd.

Hardis \& Dromedas Ltd

Hutton Chemical Inds. Ltd.
Enugu

18, Iweka Road, P. O. Box 242, Onitsha

Km 18 Onitsha/Enugu Exp. Way. P. M. B. 1580, Onitsha

KM2, Atani Road, Habour Ind. Layout, Onitsha

P. O. Box 13465, Onitsha

51A Pokobros Inds. Avenue, Habour Inds. Estate

No. 3 Umuofele Pocket Layout $9^{\text {th }}$ Mile Corner Ngwo,

Enugu

P. O. Box 657, Awka

Block 1 Unity Lane New Tyre's Mkt. Nkpor P. O. Box 6385 Onitsha.

No. 43 Obosi Road, Nkpor Junction, Obosi, Anambra

State.

$9^{\text {th }}$ Mile Corner, Enugu

P. M. B. 1549, Onitsha

P. O. Box Ihiala

4, Pokobros Ind. Avenue, Box 322, Nnewi

P. O. Box 10001, Fegge-Onitsha

4, Pokobros Group (W.A) Ltd P. O. Box 10001, Onitsha Akwu-uru Industrial Estate, P. O. Box 905, Nnewi

Plot 26 Block 2A ACME Road Ogba GPO Box 67 Lagos OR

Plot In/52 Harbour Industrial Layout off Atani Road Osha.

217A Awka Industrial Layout \& 8 Pokobros Ind. Avenue, Awka

217A Awka Industrial Layout \& Pokobros Ind. Avenue Awka.
97 Onitsha Owerri Road, Onitsha

Akwu-Uru Inds. Estate, Umudim P. M. B. 5088, Nnewi

28 Madueke St. Odoakpu P. O. Box 5835 Onitsha

15 Arch Bishop Henry Street, Odoakpu P. O. Box 2591, Onitsha.

Plot 219 Ibeagwa-Aka St. Nike Community Layout Ext. Phase 2, P. O. Box 1252, Enugu.

87 Ogui Road, Box 9233, Enugu.

P. O. Box 309, Ibusa, Delta State

Npor Umuoji Road, P. O. Box 237, Umuoji Idemili

L.G.A.

No. $11^{\text {st }}$ Avenue, Independence Layout, P. O. Box 553, Enugu.

9 Archbishop Street, Onitsha

2 Chukwubuike Close, Ozalla 40 Awka, Box 913, Onitsha

82 Upper New Market Road, P. O. Box 913, Onitsha

2 Enugu Road, P. O. Box 9, Idemili

Plot 50 Odume Layout, Obosi P. O Box 10205, Onitsha

Plot 19/83 Niger Bridge Inds. Layout, P. M. B. 17141,

Onitsha

Hardis Industrial Estate, Airport Road, Emene

7 Ichida St., Federal Housing Estate, Trans-Ekulu P. O. Box 13789, Enugu. 
Ibeto Petrochemical Co. Ltd.

Integrated Chemical Co. Ltd.

Jacbon Inds. Ltd.

Juhel Nig. Ltd.

Kates Associated Inds. Ltd.

Martha Inds. Nig. Ltd.

Michelie Laboratories Ltd.

Niger Chemicals Ind. (W.A) Ltd.

Nalin Paints Ltd.

Pegofor Industries Ltd.

Pheranzy Gas Ltd.

Promoter Industrial \& Chemical Co. Ltd. Rico Pharmaceutical Inds. (Nig.) Ltd.

Sambros Inds. Ltd.

Sharon Paints \& Chem. Co. Nig. Ltd. Specialty Oil Co. Nig. Ltd.

Whiz Oil Products (W.A.) Ltd.

F. A. Ike \& Sons Ltd.
60/61 Igwe Orizu Road, P. M. B. 50132, Nnewi

No. 3 Isuochi Street, Uwani, Enugu.

Nkpor/Obosi Rd., Obosi P. O. Box 4113, Onitsha

4 Isu-Oba Close, Trans-Ekulu, P. O. Box 1549, Enugu.

Plot 1/76 Ind. Layout, Bridge Head, P. M. B. 1669,

Onitsha.

28/29 Enugu/Ozalla Road, P. O. Box 5012, Onitsha.

Plot 23 Block 2, Thinkers Corner, Emene P. O. Box

2709, Enugu

Km 29, Onitsha-Ogbaru Road, Umunakwo

Thinkers Corner Layout, Enugu.

42/43 Iweka Road, P. O. Box 1342, Onitsha

13 Ekololu Street Off 1 Litre Road Surulere Lagos OR

Plot 278 Awka Ind. Estate, Awka.

Akwuru Industrial Layout, P. O. Box 905, Nnewi

26 Nwaifa Street, Omagba Phase II, P. O. Box 1876,

Onitsha.

9 Emeka Orazuluike St. Umumejiaku Uruagu, P. O. Box

545, Nnewi

241 Agbani Road, P. O. Box 10136, Enugu

Plot In/10 12 x 14 Niger Bridge Head Ind. L/O P.M.B

1591, Onitsha.

Plot 21713 Awka Ind. Layout, P. O. Box 583, Awka.

Km 10 Onitsha/Enugu Exp. Way, Ogidi Ikenga P.O. Box 10033.

\section{DOMESTIC \& INDUSTRIAL PLASTICS, RUBBER AND FOAM SECTORAL GROUPS}

NO. NAMES

Atuchukwu Chemical Inds. Ltd.

Awutolo Inds. Ltd.

Basmic Plastic Inds. Nig. Ltd.

Charity Foam Ind. Ltd.

Climax Ind. Ltd.

Christoplast Ind. Nig. Ltd.

Curtis-Jas Ind. Ltd.

Deco Foam \& Chem. Ind. Ltd.

Dozzy Group Ltd.

Elephant Chem. Inds. Ltd.

Emic Foam \& Allied Inds. Ltd.

Ezenwa Plastic Ind. Ltd.

Fabro Trading \& Inds. Co. Ltd.

Finoplastics Inds. Ltd.

Gabee Inds. Ltd.

Gabinson Inds. Ltd.

GASFA Inds. Ltd.

G. M. O. Rubber Products Ltd.

Godwin Okafor \& Sons Ltd.

Group Enterprises (Nig.) Ltd.

Global Concepts (W.A.) Ind. Ltd.

INNOSON Technical \& Ind. Co. Ltd.

\section{ADDRESS}

10 Atuchukwu close, Nkpor, P. O. Box 304. Onitsha

Agu Awka Inds. Layout, P. O. Box 166, Awka Awada Industrial Layout, P. O. Box 9985, Onitsha

Km 4 Onitsha/Enugu Road, P. O. Box 4292, Onitsha

48 Nanka Str. Odume Layout, Obosi, P. O. Box 410

Onitsha.

P. O. Box 10055, Fegge - Onitsha

43 Obetedit Str., Off Enugu/Onitsha Exp. Nkpor

15 Obeledu Str. Onitsha

Plot In/14 Niger Bridge head, P. M. B. 1591, Onitsha.

33 Nanka Str., Odume Layout Obosi, P. O. Box 410,

Onitsha.

1,3 \& 5 Emic Road, Odume Layout, Obosi, P. O. Box 570, Onitsha

Ichi Street, Ind. Layout Box 188, Onitsha

14 Chinton Street, Onitsha, P. O. Box 10205, Onitsha.

Plot 182 Ikenga Inds. Layout P. O. Box 14, Nwafia.

No. 5813 Old Market Road, P. O. Box 9118 Onitsha

12 Douglas Street, P. O.Box 2432, Onitsha

50, Nduka Str. Odume Obosi, P. O. Box 10306, Onitsha.

26/27 G. M. O. Rd., East Niger Inds. Layout, P. O. Box

2248, Onitsha.

Plot 231 Pokobros Avenue Ind. Layout, Awka P. O. Box 1419, Onitsha

Plot 19/83 Niger Inds. Layout, P. M. B. 17141, Onitsha.

Plot EL 7/8 Ikenga Layout, G. P. O Box 1264, Awka

Plot W/I Inds. Layout, Emene, P. O. Box 1570, Enugu. 
Johnny Young (Nig.) Ltd.

Louis Carter Inds. Ltd.

Nakpo Plastic Containers

Niccus Industries Ltd.

MAN Plastic Inds.

Matag Ltd.

Marta Inds. Ltd.

Mercury Foam Inds. Ltd.

M/S Petters \& Daniels Ind. Nig. Ltd.

Ozalla Plastic Enter. Ltd.

Peter E. Venture Nig. Ltd.

Piko Plastic Inds.

Saga Foam \& Chemical Ind. Ltd

Sa-Nwinco Inds. Ltd.

St. Mary's Inds. Complex Ltd.
6 Benjamin Street, Box 4333, Onitsha

9 Emma Okafor Str. Akabaukwu, P. O. Box 2757, Nnewi

Plot In/76 Ind. Layout Bridge Head, P. M. B. 1669,

Onitsha.

No. 43 Obosi Road, Nkpor Junction, Obosi, Anambra

State.

48 Ezeiweks Rd., Awada Box 1362, Onitsha

29 Niger Street, Fegge, P. O. Box 344, Onitsha

28/29, Enugu Ozalla Road, Odume, P. O. Box 5012,

Onitsha

18/20 Okija Str. Ozalla Layout, Obosi, P. O. Box 5012,

Onitsha.

113 Port Harcourt Rd. P. O. Box 5669, Onitsha.

Plot 253, Awka Indus. Layout, P. O. Box 865, Awka

9/11, Isiokpo Street, P.O. Box 788, Onitsha

213 Agbani Road, Box 3666, Enugu

Offor Lane/43 Obeledu Street Nkpor, P. O. Box 4

Adazi-Ani Anambra State.

9 Danco Estate, Box 1423, Onitsha

57 Nnobi Road, Box 392, Nnewi

D. DOMESTIC \& INDUSTRIAL PLASTIC, RUBBER AND FOAM SECTORAL GROUPS

NO. NAMES

Best Aluminum (Mfg) Co. Ltd.

Bonanza Inds. Co. Nig. Ltd.

Brollo Pipes and Profiles Ind. Ltd.

Gazasonner Inds. (Nig.) Ltd.

General Metals Nig. Ltd.

GINPAT Aluminium Products Ltd.

G.M.O. Galvanizing Ind. Ltd.

International Enamel Ware Ind. Ltd.

HUNT Inds. Ltd.

Jimex Inds. Nig. Ltd.

Niccus Industries Ltd.

Onitsha Aluminium Mfg. Co. Ltd.

Peter E. Ventures Inds. Ltd.

Robertson Nig. Ltd.

Vincent Standard Steel Ind. Ltd.

Homus Steel Ltd.

Alo Aluminum Mfg. Co. Ltd.

Chriscord Inds. Ltd.

\section{ADDRESS}

30D Port Harcourt Road, P. O. Box 5396, Onitsha

72 Oguta Road Onitsha

Plot In/62 Industrial Layout Onitsha

P. O. Box 680, Onitsha

No. 43 Osolo Way, Osolo-Lagos OR Enugu - Port

Harcourt Exp. Road Ndiagu Amechi Enugu South L.G.A.

Km 12, Onitsha-Enugu Express Way

Plot 38/48 Atani Road, Inds. Layout East Nigeria, Head

Bridge, P. O. Box 2574, Onitsha

P. M. B. 1617, Onitsha

97B Onitsha-Owerri Road, Onitsha

Umuanuka Village, I Industrial Avenue, P. M. B. 5005

Nnewi

No. 43 Obosi Road, Nkpor Junction, Obosi, Anambra

10 Akunnia Njote St. Woliwo, P. O. Box 1684, Onitsha

9/11 Isiokpo Street, P. O. Box 788, Onitsha

Emene Inds. Layout, P. O. Box 788, Onitsha

P. O. Box 680, Onitsha

Plot 3/2 In/5 Habour Ind. Layout, P. O. Box 14478,

Onitsha

Enugu-Abakaliki Express Way, Opp Mobil Filling

Station Enugu

Nkpor Unuoji Rd., P. O. Box 6300, Onitsha.

E. PULP, PAPER \& PAPER PRODUCTS, PRINTING \& PUBLISHING SECTORAL GROUP

NO. NAMES

African - First Publishers Ltd.

B.C. Ifegbo \& Associates Ltd.

Denson paper Mill Ltd.

L.L. Nwadike \& Associates Ltd.

Mikson Industries Ltd.

Niccus Industries Ltd.

\section{ADDRESS}

Niger Bridge Head, P. O. Box 4771, Onitsha

25 New Market Road, Box 2490, Onitsha

24 New Market Road, P. O. Box 115, Onitsha

12 New market Road, P. O. Box 5017, Onitsha

Block 1 Unity Lane New Tyre's Mkt Nkpor, P. O. Box 6385, Onitsha.

No. 43 Obosi Road, Nkpor Junction, Obosi Anambra State. 
Niger Paper Industry Nig. Ltd.

Niger Bridge Head, P. O. Box 4772, Onitsha

F. ELECTRICAL \& ELECTRONICS SECTORAL GROUP

NO. NAMES

Adswitch Plc

Benmax Cables Ltd.

Cuitix Plc.

Geoelis Cables Ltd.

P. M. S. Electrical Mfg. (Nig) Ltd.

\section{ADDRESS}

1 Metu Uzodike Str. Okpuno Otolo, P. O. Box 11139, Nnewi

Plot In/123 Emene Inds. Layout, P. O. Box 2599, Enugu. 1 Metu Uzodike Street, P. M. B. 5040, Nnewi

Nkpor Umuoji Road, Onitsha

1 PMS Road, Otolo, Nnewi, P. O. Box 8330, Marina

Lagos.

G. ELECTRICAL \& ELECTRONICS SECTORAL GROUP

NO. NAMES

ADDRESS

General Cotton Mills Ltd.

Niger-Bridge Inds. Layout P. M. B. 1601 Onitsha

H. WOOD \& WOOD PRODUCTS INCLUDING: FURNITURE SECTORAL, GROUP

NO. NAMES

ADDRESS

Dunon Furniture Ind. Ltd.

11/15 Mbanugo Street, P. O. Box 745, Enugu

Caprisage Exp. Wood \& Furniture Co. Ltd.

I. NON-METALLIC MINERAL PRODUCTS SECTORAL GROUP

NO. NAMES

Best Rose Inds. Ltd.

Emenite Ltd.

Franklin Marbel inds. Ltd.

Ibeto Industries Ltd.

Sylver Concrete Ind. Ltd.

Bonanza Inds. Co. Ltd.
ADDRESS

No. 69 Ozomagala Str., P. O. Box 13782, Onitsha

P. O. Box 646

31, Awka Road, Onitsha

60-61 Igwe Orizu Road, P. O. Box 131, Nnewi

Km3 Nkpor-Obosi Road, P. O. Box 10320,

Fegge-Onitsha

Onitsha

J. MOTOR VEHICLE \& MISCELLANEOUS SECTORAL GROUP

NO. NAMES

Alf Williams Inds. Ltd.

Anamnra Motor Mfg. Co. Ltd.

Basico Bicycle Mfg. Co. Ltd.

Cospam Nig. Ltd.

Ekene Dili Chukwu (SS) Ltd.

Ehae Adirindo Nig. Ltd.

Eziobi Motors Nig. Ltd.

Fenok Inds. Ltd.

Iju Inds. Ltd.

Innoson Nig. Ltd.

Jagua Pan-African Ind. Ltd.

Maryment Nig. Ltd.

Naco Motors Ltd.

Niger Automobile Inds. Ltd.

Omatha Automobile Products Ltd.

OCE Fitters Mfg. Ind. Ltd.

Osychris inds. (Nig.) Ltd.

Steveana Ltd.

Todson Enterprise Ltd.

Uru Inds. Ltd.

Union Autoparts Mfg. Co. Ltd.

Variations Inds. Ltd.

\section{ADDRESS}

14 New Market Road, Box 567, Nnewi

Emene Industrial Layout, Enugu

10b Osamele Str. Odoakpu Onitsha

17 Nise Street Uwani - Enugu OR 124 - 126 Enugu Rd., Nsukka

2 Ekene Dili Chukwu Rd. Awada Layout Box 210,

Onitsha

Km2 Enugu/Onitsha Expressway, Box 3183, Onitsha

Zone 12 Block A34 Store No. 2 Main Market, P. O. Box

2834, Nnewi.

Km6 Onitsha/Owerri Rd., Obosi P. O. Box 5666, Onitsha

39 Awka Road

20 New Market Road, Box 1068, Nnewi

Ohaegbu Rd., P. O. Box 192, Okija

3A New Market Road, Nnewi

37 Nnobi Road, P. O. Box 120, Nnewi

P. O. Box 4327, Onitsha

33 Omatha Holdings Factory P. M. B. 2525, Enugu.

Mile 12, New Onitsha Rod., Akabaukwu Uruagu, P. O.

Box 322 Nnewi

5, New Motorcyle Spare-parts Road, Nnewi

60 Igwe Orizu Road, Nnewi

4 Edo Ezemewi Road, P. O. Box 99, Nnewi

Akwu-uru Industrial Estate, P.M. B. 6, Nnewi

60-61 Igwe Orizu Road, P. O. Box 131, Nnewi

37 igwe Orizu Rd., P. O. Box 148 Nnewi 
Appendix VI. List of man financial member companies in Abia and Imo states

S/NO NAME AND ADDRESS

1. Umuokpara Town, Km 11 $1 \frac{1}{2}$ Old Aba/Owerri Road

Osisioma Ind. Layout, Osisioma Ngwa L.G.A.

68 Asa Road

P. O. Box 702, Aba

Telephone: 082-440590, 441814, 232058, 233653, 446105

Website: wwwadaobi.com

E-mail: info@adaobi.com adaobiplastcks@yahoo.com

Sectoral Group Domestic \& Ind. Plastic \& Rubber/Chem \& Pharm.

Sub-sector: Domestic \& Ind. Plastics/Basic lad. Chemicals

Product Manufactured: Rubber Products, Polythene bags, Solid Mineral Chemicals

2. AGAD LIMITED

5, Eze Achike Street

Off MCC/Uratta Road

Owerri

Tel: 083233608, 08033344420, 08033270926

E-mail: agad@rbow.net

Sectoral Group: Textile, Wearing Apparel \& Leather

Sub-Sector: Textile, Wearing Apparel

Product Manufactured: Garments

3. ALABA SOAP INDUSTRIES LIMITED

$46 \mathrm{Aba} /$ Owerru Road

P. O. Box 695

Tel: 082 300801, Aba

Sectoral Group: Chemicals and Pharmaceutical Group

Sub-Sector: Soap and Detergent

Products Manufactured: Laundry Soap

ALUMINIUM EXTRUSION IND. PLC

Km 4 Atta-Amaimo Road, Ikyishi, Ikeduru

P. M. B. 1581, Owerri

E-mail: alexip@phea.linkserve.com

Sectoral Group: Basic Metal, Iron \& Steel and Fabricated Metal Products

Sub-sector: Aluminiu producers

Products Manufactured: Aluminium Profiles

5. ANZZY INDUSTRIAL CO. LTD

10 Powerline/188 Faulks Road

P. O. Box 6704, Aba

Tel: 082 - 221715, Fax: 227123, 440164

E-mail; anzzy@phea.linkerve.com

Sectoral Group: Textile, Wearing Apparel \& Leather

Sub-sector: Leather Products Manufacturers

Products Manufactured: Leather, Heel Adhesive, Nails and Shoes Soles

6. BEAUTY BASE LIMITED

Aya Umueze off P.H/Enugu Exp. way

$152 \mathrm{Aba} /$ Owerri Road

P. O. Box 3223, Aba

E-mail: juhaba@alpha.linkserve.com

Sector Group: Chemical and Pharmaceuticals

Sub-sector: Soap and Detergent

Products Manufactured: Body Cream, Soap and Allied Products

7. BENA COSMETIC INDUSTRIES LTD

16/17 Chief Ogbuji St.

20A Ozuomba Road

Tel: $082-225879,225962$ 
E-mail: benamoom2000@yahoo.com

Sectoral Group: Chemical and Pharmaceuticals

Sub-Sector: Toiletries and Cosmetics

Products Manufactured: Soaps and Body Creams

8. CAMELA VEGETABLE OIL CO. LTD

Plot $\mathrm{C} 1 / 24$ Onitsha Industrial Layout

P. O. Box 852, Owerri

Tel: 090-501988, 500516, 083-233905, 082-446504

E-mail: camelaoli@yahoo.co.uk

Sectoral Group: Food, Beverages \& Tobacco

Sub-sector: Starch and other miscellaneous food products

Products manufactured: vegetable oil

9. CASCAMITE GLUE LIMITED

Kilo 1 Opodo Road, 55 Azikiwe Road

P. O. Box $714 \mathrm{Aba}$

Tel: $0802-220798,226300$, (Fax: 226751, 225486)

E-mail: tanugrup@yahoo.com

Sectoral Group: Textile, Wearing Apparel \& Leather

Sub-sector: Leather Products Manufactured

10. CHEMLAP NIGERIA LIMITED

Osisoma Industrial Layout

P. O. Box 1356, Aba

Tel: 083-440033, 350095

Sectoral Group: Chemical and Pharmaceuticals

Sub-sector: Textile, Wearing Apparel \& Leather

Products Manufactured: Resins, Adhesive

11. CHIEME MOTHERS NIG. LIMITED

33 St. Michael's Road

P. O. Box 1392, Aba

Tel: 082-222330, 225456

E-mail: chieme@phea.linkserve.com

Sectoral Group: Motor Vehicle \& Miscellaneous Assembly

Sub-sector: Automobile Components manufacturers

Products Manufactured: Car Components

12. CONSOLIDATED BREWERIES PLC

Km 24 Owerri/Onitsha Road

P. O. Box 440, Awo-Omamma

Tel: 083-800220, 232941, 232765, 230796

Sectoral Group: Food, Beverages \& Tobacco

Sub-sector: Beer

Products Manufactured: Beverages (Beer and Malt)

13. CONVERSIONS NIGERIA LTD

$7^{\text {th }}$ Mile Old Aba/Owerri Road

P. M. B. $7446 \mathrm{Aba}$

Tel: 01-616761

Sectoral Group: Pulp, paper \& paper products, printing \& publishing

14. ELCHEM LIMITED

15 Elchem Industrial Road

P. O. Box 395, Mgbidi

Tel: 082-447963

Sectoral Group: Motor Vehicle \& Miscellaneous Assembly

Sub-sector: Automobile Components manufacturers 
Product Manufactured: Elchems car wash, radiator coolant, electrolyte

15. EMPRESA JEOMEG LIMITED

48 Ehi Road

P. O. Box $6210 \mathrm{Aba}$

Tel: 082-231206, 08033181703

Sectoral Group: Chemical and Pharmaceutical Group

Sub-sector: Paints, vanishes and allied products

Products manufactured: Paints

16. FALCON BOTTLING CO. LTD

Osisioma/Old Aba Owerri Road

P. O. Box 1257, Aba

Tel: 082-231582

Sectoral Group: Soft drinks and carbonated water group

Products Manufactured: Battled water

17. GLASS FORCE LIMITED

Osusu Umueme Village, Ogbor Hill Aba

Sectoral Group: Non Metallic mineral products

Sub-sector: Glass manufacturers

Product Manufactured: Bottles

18. GMICORD INTERBIX LIMITED

Otulu Town

P. O. Box 243, Awo-Omamma, Oru West

Tel: 087-772742

Sectoral Group: Basic Metal, Iron \& Steel \& Fabricated Metal Products

Sub-sector: Nail and Wire Manufacturers Group

Product Manufactured: Nails and Wires

19. HOME CHARM PAINTS INDUSTRIES LTD

Km 5 Old Aba/Owerri Road

PMB 7131, Aba

Tel: 082-223843, 440062

Sectoral Group: Chemical and Pharmaceuticals

Sub-sector: Paints, Vanishes and Allied Products

Product Manufactured: Paints, Wood Vanish

20. HYDRO RESOURCES INDUSTRIES LTD

Iyi-Ukwuebi Spring, Umuosinta, Amuzi, Obowo

5 Mission Road, Umualum, Nekede

P. O. Box 1308, Owerri

Tel: 083-234894, 234631,233910

E-mail: uzzi@hyperia.com

Sectoral Group: Food, Beverages and Tobacco

Sub-sector: Soft Drinks and Carbonated Water

Products Manufactured: Uzzi Natural Spring Water

21. INTERNATIONAL EQUITABLE ASSOCIATION LTD

No. 1 Nicholas Road

P. O. Box 282, Aba

Tel: 082-220699, 232130 (Fax; 227792)

E-mail: equitable@phea.linkserve.com

Sectoral Group: Chemical and Pharmaceuticals

Sub-sector: Soap and Detergent

Products Manufactured: Laundry Soap, Detergent etc.

22. INTERNATIONAL GLASS INDUSTRIES LTD

New Aba Industrial Layout

PMB 7044, Aba

Tel: 082-220699

Sectoral Group: Non metallic Mineral Products 
Sub-sector: Glass Manufacturers

23.

Products Manufactured: Glass \& Allied Products

JACOBS WINES LIMITED

1 - 5 Frank Jacobs Avenue

P. O. Box 20 Mgbidi

Tel/Fax: 083-231135, 082 442501, 0803332967

E-mail: Jacobs@infoweb.abs.net

Sectoral Group: Food, Beverages and Tobacco

Sub-sector: Distillery and Blending of Spirit

Products Manufactured: Wines, Spirit, Starch and Juice

24. KARISTO INDUSTRIAL SYSTEMS LTD

$\mathrm{Km} 1.5 \mathrm{Aba} /$ Umuahia Expressway

P. O. Box 5300, Aba

Tel: 082-221949

Sectoral Group: Basic Metal, Iron \& Steel and Fabricated Metal Products

Sub-sector: Distillery and Blending of Spirit

Products Manufactured: Wines, Spirit, Starch and Juice

25. KITCHEN VEGETABLE OIL LTD

$152 \mathrm{Aba} /$ Owerri Road

P. O. Box 3223, Aba

Tel: 082-350157-9, 350160

Sectoral Group: Food, Beverages \& Tobacco

Sub-sector: Vegetable/Edible Oil

Products Manufactured: Vegetable Oil

26. KORAMA CLOVER INDUSTRIAL LTD

Km 6 Old Aba/Owerri Road

P. O. Box 1345, Aba

Tel: 082-350101, 350100, 440019

E-mail: korama@yahoo.com cloverpains@hotmail.com

Sectoral Group: Chemical and Pharmaceuticals

Sub-sector: Paints, Vanishes and Allied Products Group

Products Manufactured: Paints, Wood Variables

27. LEKWAS METAL WORKS LTD

$\mathrm{Km} 2.5 \mathrm{Aba} / \mathrm{PH}$ Expressway, Alaoji

142 Ehi Road

P. O. Box 606, Aba

Tel: 082-220055, 230103, Fax: 237104

E-mail: lekwasmetal@yahoo.com

Sectoral Group: Basic Metal, Iron \& Steel and Fabricated Metal Products

Sub-sector: Nail and Wire Manufacturers Group

Products Manufactured: Wire and Nails

28. LEO MELOS PHARM. IND. LTD

301 Old Aba/Owerri Road

P. O. Box 188, Aba

Tel: 082-226410, 352061, 350067, 440111

E-mail: 1comeless2000@yahoo.com

Sectoral Group: Chemical and Pharmaceutical

Sub-sector: Pharmaceutical

Products Manufactured: Drugs

29. LIMCA BOTTLES PLC

Limca Junction, Enugu/PH Expressway

P. O. Box 236, Okigwe

Tel: 083-231671

Sectoral Group: Food, Beverages and Tobacco

Sub-sector: Soft Drinks and Carbonated Water 
Products Manufactured: Soft Drinks, Sachet Water

30. MAWATEC INDUSTRIES LTD

Km 4 Orlu/Owerri Road

P. O. Box 293, Orlu

Tel: 083-520122, 520522, 082-440714

Sectoral Group: Food, Beverages and Tobacco

Sub-sector: Star and Miscellaneous Food Products

Products Manufactured: Vegetable Oil, PKO and PKC

31. NICEN INDUSTRIES LIMITED

Km 6 Old Aba/Owerri

Osisioma Industrial Layout

Tel: 082-441788, 082 - 222688, Aba

Sectoral Group: Chemical and Pharmaceutical Group

Sub-sector: Paints, Vanishes and Allied Products

Product Manufactured: Paints and Plastics

32. PGN LIMITED

$\mathrm{Km} 1 \mathrm{Aba} /$ Umuahia Expressway

P. O. Box 214

Tel: (082) 353545, 08035232330, Aba

E-mail: ngn1000@yahoo.com

Sectoral Group: Basic Metal, Iron \& Steel and Fabricated Metal Products

Sub-sector: Aluminium Producers

Products Manufactured: Longspan Aluminium, Tower Step Tiles, etc.

33. POLEMA INDUSTRIES LIMITED

Old Aba/Owerr Road, Osisioma, near NNPC Depot

31 Okigwe Road

P. O. Box 2582

Tel: 082-222388, 227081

Sectoral group; Food, Beverages and Tobacco

Sub-sector: Star and other Miscellaneous Food Products

Products Manufactured: PKO, PKC

34. ROKANA INDUSTRIES PLC

5 Mission Road, Nekede

P. O. Box 1270 Owerri

Tel: 083-234894, 234631, 233910, 01-4970100

E-mail: rokana@infoweb.abs.net

Sectoral Group: Chemical and Pharmaceuticals

Sub-sector: Domestic Insecticide and Acrosol

Products Manufactured: Toothbrush, Air Freshener, Body spray etc.

35. SACLUX INDUSTRIES NIG. LIMITED

Umuoko Amuzukwu Ibeku

10 Lock-up Shop, Warri Str. Umuahia

Tel: 088-222653, 082-440145

E-mail: sacluxpaints@yahoo.com

Sectoral Group: Chemical and Pharmaceuticals

Sub-sector: Paints, variables and Allied Products Group

Products Manufactured: Paints, Vanish

36. SEAMASTER INDUSTRIES NIG LTD

Abor Umuazihe Amaifeke (Off Owerri Rd., Junction)

P. O. Box 1111, Orlu

Tel: 082-440775, 083-520356, 520341

Sectoral Group: Food, Beverages and Tobacco

Sub-sector: Starch and other Miscellaneous food products group

Products Manufactured: PKO, PKC

37. STARLINE NIGERIA LIMITED 
Plot 10 - 14 Eziama Industrial Layout

152 Azikiwe Road

P. O. Box 562, Aba

Tel/Fax: 082-221686, 220214

E-mail: starline@starline.com

Sectoral Group: Chemical and Pharmaceuticals

Sub-sector: Toiletries and Cosmetic Group

Products Manufactured: Cosmetics

38. STAR PAPER MILL LIMITED

114/116 Aba/Owerri Road

PMB 7376, Aba

Tel: 082-222473, Fax: 221472, 090-500269

E-mail: star@alpha.linserver.com www.starpapermil.com

Sectoral Group: Pulp, paper products, Printing \& Publishing

Sub-sector: Pulp, Paper \& Paper Products Group

Products Manufactured: Tissue paper \& Stationeries

39. TEEGEE NIG MFG. \& CO., LTD

37A New Ind. Layout

P. O. Box 2872, Owerr

Tel: 083-234232

E-mail: teegee@infowed.abs.net

Sectoral Group: Basic Metal, Iron, \& Steel and Fabricated Metal Products

Sub-sector: Nail and Wire Manufacturers Group

Products Manufactured: Nail

40. TONIMAS NIGERIA LIMITED

11 Port Harcourt Road

Km 8 Aba/Umuahia Exp. Way Aba

P. O. Box 3273, Aba

Tel: 082-2232968, 231122, 447696

Sectoral Group: Chemical and Pharmaceuticals

Sub-sector: Petroleum Refinery

Products Manufactured: Lubricating Oils

41. TOPTREE OIL MILL LTD

$\mathrm{Km} 5 \mathrm{Enugu} / \mathrm{P} . \mathrm{H}$. Expressway

P. O. Box 1268 Aba

Tel: 090-501770, 222751, Fax: 440018

E-mail: toptreeoil@yahoo.com

Sectoral Group: Food, Beverages and Tobacco

Sub-sector: Star and other miscellaneous food products group

Products Manufactured: Refined PKO Oil, (Vegetable Oil) Pal Kernel Oil

Install Capacity: 100 Metric Tons perday

42. TURA INTERNATIONAL LIMITED

J. Udeagbala Factory Premises

Ayaba, Umueze, Aba

Sectoral Group: Chemicals \& Pharmaceutical Group

Sub-sector: Soap and Detergent Group

Product Manufactured: Soap

43. TWINSET INDUSTRIES LIMITED

29/30 MCC Road Abayi Aba

Tel/Fax: 08225154

Sectoral Group: Food, Beverages and Tobacco

Sub-sector: Soft drinks and carbonated water group

Products Manufactured: Bottled water, be cream

Install Capacity: 2,000 Packets of 0.51, bottle/day 
44. Engr. Ina Uba Obasi LIKO NIGERIA LIMITED

47, Str. Michael's Road

P. O. Box 4701, Aba

Tel: $082-223799,08033418320$

Sectoral Group: Basic Metal, Iron \& Steel \& Fabricated Metal

Sub-sector: Galvanize Iron Sheet Manufacturers Group

45. UNITED STEEL CONVERTERS LTD

214 Port Harcourt Rd.,

P. O. Box 292, Aba

Tel; 082 - 220170, 224425, 440409, 225250 Fax: 233508

E-mail: USCL@phea.linkserve.com

Sectoral Group: Basic Metal, Iron \& Steel Fabricated Metal

Sub-sector: Galvanize Iron Sheet Manufacturers Group

Products Manufactured: Galvanize roofing sheets

46. UNIVERSAL OILS LTD

216218 PJI Rd.

P. O. Box $6630, \mathrm{Aba}$

Tel: 082-224609, 220500, 221690, Fax: 082-223936

Sectoral Group: Food, Beverages and Tobacco

Sub-sector: Star and other Miscellaneous food products

Products Manufactured: PKO, Vegetable Oil

47. ZAN COSMETIC IND. LTD

$\mathrm{Km} 2.5 \mathrm{PH} /$ Enugu Exp. Way

P. O. Box 12130, Aba

Tel: 082-225347, 227906

Sectoral Group: Chemical and Pharmaceuticals

Sub-sector: Toiletries and Cosmetics

Products Manufactured: Soap, cosmetics

Install Capacity: 150,000 tons

48. ZANDOB INDUSTRIAL LTD

Okpokorala Umuode-Obia, Enugu/PH Exp. Way

3D Cemetry Road

P. O. Box 7233, Aba

Sectoral Group: Food, Beverages and Tobacco

Sub-sector: Distillery and Bleeding of Spirit

Products Manufactured: Wine and Spirit

Install Capacity: $1.2 \mathrm{~m}$ Cartons per annum

49. GOODY A. DECORATORS LIMITED

1, Okigwe Road

P. O. Box 20240, Aba

Tel: 082-225617

Sectoral Group: Non-Metallic Mineral Products

Sub-sector; Absetors Manufacturers Group

Product Manufactured: Ceiling Products

50. CITRACO INDUSTRY LIMITED

253/255 Aba/Owerri Road

P. O. Box 12031, Aba

Tel:

Sub-sector: Leather products Manufacturers Group

Product Manufactured: Shoes, Plastic \& Leather Shoes 